\title{
Institutional Factors Affecting the Academic Performance of Public Administration Students in a Nigerian University
}

\author{
Ogbogu Christiana Osaikhiuwu ${ }^{1}$ \\ ${ }^{1}$ Department of Public Administration, Faculty of Administration, Obafemi Awolowo University, Ile-Ife, Nigeria \\ Correspondence: Ogbogu Christiana Osaikhiuwu, Department of Public Administration, Faculty of \\ Administration, Obafemi Awolowo University, Ile-Ife, Nigeria. Tel: 234-80-3426-5522. E-mail: \\ tinaogbogu@yahoo.com; cogbogu@oauife.edu.ng
}

\author{
Received: September 11, 2014 Accepted: September 22, 2014 Online Published: October 29, 2014 \\ doi:10.5539/par.v3n2p171 \\ URL: http://dx.doi.org/10.5539/par.v3n2p171
}

\begin{abstract}
This study investigated the institutional factors which affect the performance of Public Administration students in a Nigerian University. Primary data were obtained through the administration of questionnaires on 131 final year students of Public Administration using the purposive sampling technique. The instrument yielded a positive reliability test of 0.76 using the cronbach alpha. Retrieved data were analysed using Pearson's Correlation, factor analysis and simple percentages. Results showed that just $53 \%$ of the students performed above average with a CGPA of 3.0. However, the result of the Pearson correlation coefficient $(r=-0.052,0.152$ and - 0.071) generally revealed that the institutional variables considered (such as unfavourable learning conditions, interrupted water supply, poorly equipped library etc) did not have any significant impact on students' performance $(p>0.05)$. The study therefore concluded that students' academic performance could be influenced by some other factors which should be investigated in future research.
\end{abstract}

Keywords: institutional factors, performance, Public Administration students, Nigerian University

\section{Introduction}

Universities are engines for economic growth committed to building a skilled workforce. They teach, conduct research to advance knowledge and promote creativity and innovation. Nigerian Universities were established to pursue the goals of developing skilled and cultured citizens who could function as leaders in the society and also inherit the mantle of leadership from the colonialists shortly after independence in 1960 (Erero, 1996). However, with Universities currently facing huge financial and structural changes and juggling competing priorities, they are unable to fulfill these major roles. Universities in Nigeria contend with crises of major proportions which not only threaten their capacity to meet the challenges posed by the demands of the $21^{\text {st }}$ century and beyond but also impact on their ability to fulfill their roles of producing skilled manpower for national development (Sanda, 1991). The crises is attributed to the inability of Nigerian government to sufficiently fund her universities due to the growing enrollments, economic depression as well as the current global economic downturn which demands that governments improve efficiency in financial resource allocation and utilization. This has contributed to the challenges which degrade students' performance. Some of such institutional factors which affect students' performance include: poor funding, lack of frequent curricular review, overpopulation, students' unrest, staff strikes, poor infrastructure, poor relations between the university and government and inadequate teaching and research facilities (Ogbogu, 2011). The poor performance of students which has become a challenging problem for the academic community has wide ranging implications for national development. Students perform poorly because the institutions have failed to create the environment that is accommodating and conducive to their learning and educational needs (Harb \& El-Shaawari, 2006). The facilities available in most Nigerian Public Universities do not suffice in enhancing students learning and performance. Students therefore find it difficult to cope with the workload.

Performance is vital because the level of success students achieve from the University has far-reaching implications for their personal and professional lives. Students' performance impact on their career choice, personal income and level of success, as well as the degree of participation in community life (Grainen, 1995). Although a number of some personal and social factors such as family income, self-motivation, inability to manage school work and students' personal circumstances, amongst others have contributed to the declining 
performance of many students, their impact vary with context (Park \& Kerr, 1990).

In view of the current poor state of Nigerian Universities, this study sought to identify the institutional factors that affect students' academic performance and proffered strategies for addressing them. In doing this an attempt was made to establish relationships between selected institutional factors and academic performance measured in terms of the students' cumulative grade point average. The choice of these factors is based on the fact that Nigerian Universities are threatened with adverse economic conditions and unhealthy intellectual environment that the fundamental effectiveness of the institutions to produce competent, skilled and employable graduates is in doubt. The thrust of this study is to ensure that the Universities are restructured to be able to meet the challenges posed by the demands of the $21^{\text {st }}$ century and beyond and to be able to fulfill its mandate of producing skilled manpower for national development. Also, the findings of this study would enable universities allocate their resources accordingly to increase performance and individual productivity.

\section{Literature Review}

A number of research work has been carried out to identify and examine the myriad of factors that account for the decline in the performance of students in Public Universities in Nigeria. This has become imperative because students' performance has far-reaching implications for their personal and professional lives as well as their academic self-esteem and perseverance in the University system. Students' performance plays an important role in the country's economic and social development. It also determines the degree and nature of their participation in community life (Durden \& Ellis, 1995). This literature review therefore provides a brief examination of some of the factors that could influence students' academic performance.

Underfunding of Nigerian Universities has limited their ability to effectively and efficiently perform their traditional duties of teaching and research and has also affected their capacity to improve the state of their physical facilities which are crucial to teaching and research (Bamiro \& Adedeji, 2010).Thus, students' performance has dropped because the factors that previously enhanced the performance of Universities have been negated. Apart from underfunding, a combination of factors influencing academic performance could vary from one academic environment to another and from one cultural setting to another. For instance, students' characteristics such as their age, entry qualifications, self-motivation and work ethics could impact on their performance (Abbasi \& Mir, 2012).Other studies identified students' efforts (Siegfried \& Fels, 1979; Anderson \& Benjamin 1994), parents' education, family income, learning preferences(Aripin, Mahmood, Rohaizad, Yeop \& Anuar, 2008), class attendance (Romer, 1993) and entry qualifications as factors that significantly affect students' academic performance in various settings. Kraft and Singhapakdi (1991) confirmed that students with strong work ethics are strongly committed to their work, more dedicated, focused and tend to perform better than their peers. Thus the role of individual students' efforts towards enhanced performance cannot be over emphasized. In view of this, Abbasi and Mir (2012) posited that students themselves play critical roles in getting good grades and must therefore explore all opportunities available within their academic environment.

Romer (1993) recognized the importance of class attendance in enhancing students' performance. He found that in his economics class, students who attended class regularly made the highest grades. Durden and Ellis (1995) however attributed the decline in class attendance to assessment pressures, poor method of delivering lectures, web-based learning approaches and timing of lectures; while Newman-ford, Lloyd and Thomas (2009) attributed it to financial constraints. They argued that students, who seek employment to be able to meet up with academic financial obligations, are bound to be exhausted from working and consequently miss classes.

Although Borde (1998) found that age and gender influenced academic performance in varying contexts and noted that mature students performed better than the younger ones, he however observed that this comparison depended on the subject matter and types of assessment used. Woodfield and Earl-Novell (2006) found that female students outperformed their male counterparts. They attributed this partly to female students being more conscientious and less likely to miss lectures. Other determinants of students' academic performance according to Zimmerman, Bandura and Martinez-Pons (1992) include: students' academic background, changing academic goal, inability to manage normal schoolwork and lack of basic and fundamental skills. The impacts of these determinants vary with context and not all factors are relevant for a particular context.

Apart from traditional variables of students' efforts, Lizzio, Wilson and Simons (2002) noted that institutional environment and facilities have significant impact on students' performance. For instance, Darling-Hammond and Synder (2001) claimed that a reduction in class-size could enhance learning, while availability of adequate research equipment and teaching materials could significantly improve students' performance. They also maintained that student-teacher ratio, physical resources, equipment and teaching aids have significant effect on academic achievements. In the same vein, Devadoss and Foltz (1996) opined that a physical environment with 
improved facilities provide comfort, security, better understanding of courses and can be dramatic in terms of increased learning and performance. They further emphasized that a social interactive environment encourages participation and enhances students' creative skills. According to them an interactive environment in which students are given the freedom to choose tasks, supported for unusual ideas, taught to learn from failures and encouraged to participate in decision making enhance their skills and achievement.

According to Abbasi and Mir (2012) physical resources and staff competence are important in determining the performance of students. For instance, Trigwell, Prosser and Waterhouse (1999) emphasized the fact that effective teaching results in better learning outcomes and increases students' quantitative academic outcomes. Hence improving teacher quality can be used as a tool in increasing students' achievements. Heinesen (2010) further affirmed that teachers' ability and competence prove significant in improving students' performance and that instructors' teaching style enhances understanding of concepts taught. Benware and Deci (1984) suggested the need for Universities to provide some of the following physical facilities within its environment to enhance performance: conducive hostel facilities with inbuilt study rooms, special facilities for the physically challenged who encounter greater academic challenges, career centre designed to provide career counseling activities, equipped libraries and provision of computer and internet facilities. All of these according to Lan (2003) combine to promote students' educational growth. Engin-Dermir (2009) opined that lecturers play crucial roles in promoting educational growth and performance. He affirmed that teacher's qualification, knowledge of the subject matter, enthusiasm, interaction with students, method of lecture delivery and encouraging participation in discussions have positive and significant impact on students' achievements. Engin-Demir (2009) therefore recommended the need for the use of appropriate teaching methods, facilities and basic electronic components by teachers to facilitate learning. They emphasized the dramatic effect this has on the students in terms of increased learning and performance. In the same vein, James (1998) and Gainen (1995) recommended the need for inclusive teaching and learning approaches responsive to the varying levels of academic needs. These according to them provide sites for interactions between staff, students and institutional structures. Since institutional facilities have a great impact on students' academic performance, universities should be committed and willing to develop strategies that can facilitate learning within their environments.

\section{Methodology}

This study was carried out in Obafemi Awolowo University, one of Nigeria's first generation universities located in the South western part of the country. This University was chosen because of its status as a first generation University, which implies that it is older and well established with better facilities than the more recent ones. First generation Universities refer to those Universities that were established shortly after Nigeria gained her independence in 1960.The study which adopted the survey research design utilized data from both primary and secondary sources. Secondary data were derived from relevant text books, Journals and Internet materials, while the primary data were obtained through the administration of questionnaires on 131 final year students of the Department Public Administration, using the purposive sampling technique. As an adviser to the students, the questionnaires were personally administered by the researcher to the students in class just before the commencement of their lectures. The Students were informed about the objectives of the study and the fact that participation in the survey was voluntary. The positive retrieval of the questionnaires was due to the fact that they were filled and returned on the spot. The questionnaire consisted of three sections, the first section solicited demographic information from the respondents, including their current cumulative grade point average (CGPA); the CGPA was used in measuring their performance. The second section solicited students' responses on the institutional factors that affected their academic performance. Questions in the third section enabled the respondents to specify the extent to which the identified factors affected their academic performance. This section also enabled the respondents recommend methods for enhancing students' performance. The instrument was tested for reliability using the cronchach alpha which yielded a reliable coefficient score of 0.760 . The retrieved data were analysed using the simple percentage, factor analysis and Pearson's correlation.

\section{Results and Discussion}

\subsection{Demographic Characteristics of the Sample}

The demographic results of the respondents revealed that $41.2 \%$ of the students were males, while the remaining $58.8 \%$ were females. In terms of age, majority $(64 \%)$ of the students were between $20-25$ years, indicating that they were matured. Majority of them (70\%) resided on campus while the remaining $30 \%$ lived outside the campus. In respect of performance, the result showed that $73 \%$ of the students had a cumulative grade point average (CGPA) of 3.0, indicating that more than half of the students would graduate with a second class lower degree which is not a very impressive performance. 


\subsection{Institutional Factors Affecting Students' Performance}

Table 1 below presents the frequency distribution of the factors considered by the respondents to affect their academic performance.

Table 1. Institutional factors affecting students' performance

\begin{tabular}{lll}
\hline Factors & Frequency & Percentage (\%) \\
\hline unfavourable learning environment & 64 & 48.9 \\
Poorly equipped departmental and central libraries & 14 & 10.7 \\
Method of lecture delivery & 39 & 29.8 \\
Overcrowded lecture rooms & 67 & 51.1 \\
Unavailability of recommended texts & 46 & 35.1 \\
Late provision of reading/reference materials by lecturers & 42 & 32.1 \\
Method of collating and accessing semester results & 53 & 40.5 \\
Poor lecturer/student relationship & 29 & 22.1 \\
Interruption of electricity supply & 66 & 50.4 \\
Poor access to internet facilities & 39 & 29.8 \\
Interruption of water supply & 42 & 32.1 \\
Incessant strike and closure of school & 65 & 50 \\
Poor accommodation facilities & 64 & 48.9 \\
Overcrowded exam time table & 10 & 7.6 \\
\hline
\end{tabular}

Majority of the respondents reported that overcrowded lecture rooms (51.1\%), interruption of electricity supply $(50.4 \%)$ and incessant strike and closure of school $(50 \%)$ were the factors that mostly affected their performance. This result is consistent with Karemera's (2003) study, where he found that overcrowded lecture rooms did not provide a quiet study environment and that students' performance were significantly correlated with conducive study environment. This result also supports the views of a student in a typical Nigerian Public University as contained in the excerpt from Erero's (1996) study:

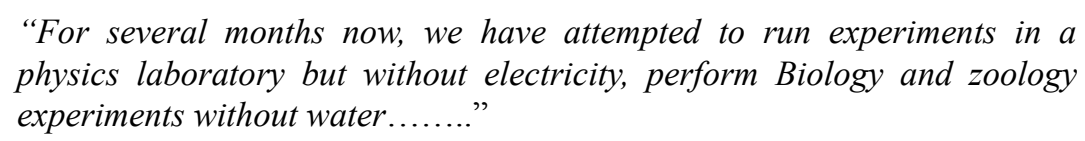

It is evident that inadequate supply of electricity makes studying and other academic activities cumbersome.

Furthermore, the table shows that $40.5 \%$ of the respondents reported that the method of collating and accessing semester results affected their performance, while $48.9 \%$ of the respondents reported that poor accommodation facilities and unfavourable learning environment also affected their academic performance. These findings agree with Abbas and Mir's (2012) study that reported that physical environment and the conditions of the facilities in higher educational institutions provide comfort and better understanding of courses taught, hence affecting students' learning and ultimate achievement. The following excerpt from Erero's (1996) study also corroborates this result:
"A student describes a day in the university life. She rises before first light, roles up her sleeping mat and leaves the room, in the hall of residence, which she shares with eleven others. The room had been furnished for two students in the early years, then bunks were installed to permit four to be housed...there is water crisis on campus ... she takes her bucket and walks to join the queue... it is hours before she is able to fill her bucket and return to the hostel... She goes to class where it is standing room only ... she is late and joins others at the windows. It is difficult to hear the lecturer, or see the board..."

These evidences reveal that the poor condition of hostels and some other facilities in the system which are 
attributed to government's negative attitude towards funding of Universities significantly affect students' performance. The pattern of financing Universities is socially inequitable and economically inefficient, thus government needs to reverse this negative trend. Results on the table also reveal that the rate of respondents' opinions on the other variables that affect their performance were low and below $40 \%$, with the least (7.6\%) being overcrowded examination time-table. Generally however, results on the table indicate that a combination of economic conditions, conditions of the basic facilities in the university, state of the intellectual environment and a sense of anomie have impacted on the performance of the students.

Factor analysis was performed on the institutional factors considered to affect students' performance as shown in Table 2 below:

Table 2. Factor analysis

\begin{tabular}{ll}
\hline Institutional factors & Factor loading \\
\hline Factor I (cronbach alpa $=\mathbf{0 . 7 6}$ ) & \\
\multicolumn{1}{c}{ Kmo $=\mathbf{0 . 6 8}$} & .621 \\
Lecturer / student relationship & .697 \\
Method of lecture delivery & .797 \\
Hostel accommodation & .802 \\
Interruption of water supply & .782 \\
Interruption of electricity supply & \\
Factor 2 & .773 \\
Conditions of lecture rooms & .833 \\
Overcrowded classrooms & .503 \\
Incessant closure of school & \\
Factor 3 & .714 \\
Library facilities & \\
Access to internet & .796 \\
Facilities & \\
\hline
\end{tabular}

The table presents the factor analysis performed with varimax rotation. It also shows the factors obtained, the factor loadings and the items that compose each set of factors. The Table also presents the result of the test of reliability carried out using the cronbach alpha and that of appropriateness using the Kaiser-Meyer-Olkin (kmo) measure of sampling adequacy. All the results indicated that factor analysis was an appropriate technique and the instrument used was reliable. The kmo test yielded a positive result of 0.68 , while that of the cronbach alpha (0.76) was also positive. The result of the factor analysis revealed that the scores represent significant factor loadings (i.e. above 0.5 ) of individual items listed which is an indication that they were internally consistent. The result of the factor analysis also shows that the institutional factors considered to affect students' performance were also closely related.

Based on the results of the factor analysis, further investigation was carried out using the Pearson's correlation to determine the extent to which the institutional factors significantly affected students' performance. This is shown in Table 3 below:

Table 3. Pearson correlation table

\begin{tabular}{llll}
\hline Factors & & & Performance (CGPA) \\
\hline Factor 1 & N & R & P-value \\
Factor 2 & 86 & -0.052 & 0.634 \\
Factor 3 & 81 & 0.152 & 0.177 \\
\hline
\end{tabular}


The result of the correlation coefficient $(\mathrm{r}=-0.052,0.152$ and -0.071$)$ reveal that the institutional factors considered did not significantly affect students' performance. Also, the P-values $(0.634,0.177$ and 0.510$)$ were more than 0.05 (i.e. $\mathrm{P}>0.05$ ) showing that the factors were not significant. This result shows that institutional factors alone did not significantly affect students' performance, which implies that a myriad of some other factors such as students' age, work ethics, self-motivation, socio-economic status and some others could play significant roles in determining students' performance. This result is consistent with Sirin's (2012) study that established the fact that it is nearly impossible to predict students' performance using institutional variables alone; rather their performance is contingent upon a number of some other factors. Generally, the result of this study is logical as it clearly demonstrates that institutional factors no matter how important they are cannot influence the performance of students in isolation of some other factors.

\section{Conclusion}

In this paper an attempt was made to locate the institutional factors that affect the academic performance of students in one of Nigeria's first generation Universities. This paper chose to focus on institutional factors due to the obvious crisis of major proportions contending with Nigerian universities which threaten their capacity to fulfill their roles of producing skilled manpower for national development. Although analysis of the data using descriptive statistics revealed that the interruption of electricity supply, overcrowded lecture rooms, unfavourable learning environment, incessant strike and closure of school as well as method of collating results were found to affect students' performance more than the others; results of further analysis of the data using Pearson correlation however revealed that generally, institutional factors alone did not significantly affect students' performance. The paper therefore argued that a myriad of some other endogenous and exogenous factors play significant role in determining students' performance and these need to be investigated in future research.

\section{References}

Abbasi, A. R., \& Mir, G. M. (2012). Impact of teacher's ability, students' work ethics and institutional environment on student performance at university of Gujrat. Middle-East Journal of scientific Research, 2(4), 572-579.

Anderson, G., \& Benjamin, D. (1994). The determinants of success in university introductory Economics courses. Journal of economic education, 25(2), 99-119. http://dx.doi.org/10.1080/00220485.1994.10844820

Aripin, R., Mahmood, Z., Rohaizad, R., Yeop, U., \& Anuar, M. (2008). Students'learning styles and academic performance. $22^{\text {nd }}$ Annual SAS Malaysia Forum. $15^{\text {th }}$ July 2008. Kuala Lumpur convention center, Kuala Lumpur, Malaysia.

Bamiro, O. A., \& Adedeji, O. S. (2010). Sustainable financing of higher education in Nigeria. Ibadan: Ibadan University Press.

Benware, C., \& Deci, E. (1984). Quality of learning with an active versus passive motivational set. American Educational Research Journal, 21(2), 755-765. http://dx.doi.org/10.3102/00028312021004755

Borde, S. F. (1998). Predictors of Student academic performance in the introductory marketing course. Journal of Education for Business, 73(5), 302-307. http://dx.doi.org/10.1080/08832329809601649

Darling-Hammond, L, Berry, B., \& Thoreson, A. (2002). Does teacher certification matter? Evaluating the evidence. Educational Evaluation and Policy Analysis, 23(91), 57-77.

Devadoss, S., \& Foltz, J. (1996). Evaluation of factors influencing students' attendance and performance. American Journal of Agricultural Economics, 78(3), 499-507. http://dx.doi.org/10.2307/1243268

Durder, G. C., \& Ellis, R. V. (1995). The effects of attendance on students' learning in Principles of Economics. American Economic Review, 85(2), 343-346.

Engin-Demir, C. (2009). Factors influencing the academic achievements of the Turkish urban poor. International Journal of Educational Development, 29(1), 17-29. http://dx.doi.org/10.1016/j.ijedudev.2008.03.003

Erero, E. J. (1996). Towards the Nigerian University of the $21^{\text {st }}$ Century: Challenges and opportunities. In T. Omole, \& I. Nassar (Eds.), Nigerian Administration beyond the year 2000. A. D: challenges and opportunities.

Gainen, J. (1995). Barriers to success in quantitative gate keeper courses. In J. Gainen, \& E. W. Williamson (Eds.), Forstering student in quantitative gateway courses (pp. 5-14). San Francisco: Jossey Bass.

Haist, S. A., Wilson, J. E., Elan, C. L, Blue, A. V., \& Fosson, S. E. (2000). The effect of gender and age on medical school performance: An important interaction. Advances in health sciences Education, 5(3), 
197-205. http://dx.doi.org/10.1023/A:1009829611335

Hard, N., \& El-Shaarawi, A. (2006). Factors affecting students' performance. Munich personal Repec Archive paper No. 13621.

Heinesen, E. (2010). Estimating class-size effects using within school variation in subject specific classes: An important interaction. Advances in Health Sciences Education, 5(3), 197-205.

James, D. (1998). Higher Education field-work: the interdependence of teaching, research and student experiences. In M. Grenfell, \& D. James (Eds.), Bourdien and Education: Acts of practical theory (pp. 104-121). London: Falmer press.

Karemera, D. (2003). The effects of academic environment and background characteristics on students' satisfaction and performance. The case of South Carolina State University's school of Business. College student Journal, 37(2), 298-11.

Kraft, K. L., \& Singhapakdi. (1991). The role of ethics and Social responsibility in achieving organizational effectiveness: Students versus managers. Journal of Business ethics, 10(9), 679-686. http://dx.doi.org/10.1007/BF00705874

Lau, L. K. (2003). Institutional factors affecting students' retention. Education, 124(1), 126-136.

Lizzio, A., Wilson, K., \& Simons, R. (2002). University students' perception of learning environment and academic outcomes: Implications for theory and practice. Studies in Higher Education, 27(1), 27-52. http://dx.doi.org/10.1080/03075070120099359

Mlambo, V. (2011). An analysis of some factors affecting students' academic performance in an introductory biochemistry course at the University of the West Indies. Caribbean Teaching Scholar, 1(2), 79-92.

New man - Ford, L., Lloyd, S., \& Thomas, S. (2009). An investigation in the effects of gender, prior academic achievement, place of residence, age and attendance on first year undergraduate attainment. Journal of applied research in Higher Education, (1), 13-28.

Ogbogu, C. O. (2011). Modes of funding Nigerian Universities and the implications on performance. Paper presented at the 2011 Barcelona European Education conference NH Calderon, Rambla, Barcelona, Spain.

Park, K. H., \& Kerr, O. M. (1990). Determinants of academic performance: A multinomial logit approach. Journal of Economic Education, 21(2), 101-111. http://dx.doi.org/10.1080/00220485.1990.10844659

Romer, P. (1993) Do students go to class? Should they go? Journal of economic perspectives, 7(3), 167-174.

Sanda, A. O. (1991) Understanding Higher Educational Administration in Nigeria. Ibadan: Fact Finder International.

Siegfried, J., \& Fels, R. (1979) Research on Teaching College economics: A survey. Journal of economic Review, 17(3), 923-939.

Sirin, S. R. (2005). Socio economic status and academic achievement: A meta-analytic review of research. Review of Educational Research, 75(3), 417-453. http://dx.doi.org/10.3102/00346543075003417

Trigwell, K., Prosser, M., \& Waterhouse, F. (1999). Relations between Teachers' approaches to teaching and $\begin{array}{lllll}\text { students' } \text { approaches to learning. Higher Education, 37(1), } & \text { 57-70. }\end{array}$ http://dx.doi.org/10.1023/A:1003548313194

Woodfield, R., \& Earl- Novell, S. (2006). An assessment of the extent to which subject variation in relation to the award of first class degrees between the Arts and Sciences can explain the 'gender gap'. British Journal of sociology of Education, 27(3), 355-372. http://dx.doi.org/10.1080/01425690600750569

Zimmerman, B. J., Bandura, A., \& Martinez-Pons, M. (1992). Self- motivation for academic attainment: The role of self-efficacy beliefs and personal goal setting. American Educational Research Journal, 29(3), 663-676. http://dx.doi.org/10.3102/00028312029003663

\section{Copyrights}

Copyright for this article is retained by the author(s), with first publication rights granted to the journal.

This is an open-access article distributed under the terms and conditions of the Creative Commons Attribution license (http://creativecommons.org/licenses/by/3.0/). 